\title{
AKSELERASI:
}

\section{STRATEGI GURU DALAM MENGIMPLEMENTASIKAN PENDIDIKAN MULTIKULTURAL PADA SEKOLAH DASAR DIMASA PANDEMI COVID-19}

\author{
Firman Aulia Ramadhan, ${ }^{1}$ Lailatul Usriyah ${ }^{2}$ \\ ${ }^{1}$ UIN Kiai Haji Achmad Shiddiq, Jl. Mataram No.1 Mangli Jember, Jawa Timur Indonesia \\ e-mail: firmandhan99@gmail.com \\ ${ }^{2}$ UIN Kiai Haji Achmad Shiddiq, Jl. Mataram No.1 Mangli Jember, Jawa Timur Indonesia \\ e-mail: lailatulusriyah1978@gmail.com
}

\begin{abstract}
This study aims to explain an overview of teacher strategies in implementing multicultural education in elementary schools during the Covid-19 pandemic. Along with the Covid-19 pandemic and the implementation of social distancing and physical distancing policies in an effort to reduce the spread of the virus. In this study, the researcher used a qualitative research method with a research design in the form of library research. The research instrument used is in the form of documentation and observation. Based on research results that the implementation of multicultural education values in elementary schools during the covid-19 pandemic can be applied by instilling or inserting multicultural values themselves into core learning competencies in the form of online (online) using platforms such as Google Meet. ,Zoom,Whatsapp Group and Google Classroom. And Outside the Network (Offline) by Using Student Handbooks, Modules, LKS (Student Worksheets) and others. The forms of activities are a) student-oriented programs. b) Material-oriented programs c) socially oriented programs.
\end{abstract}

Keywords: Teacher Strategies, Multicultural Education, Covid-19 Pandemic.

\begin{abstract}
ABSTRAK
Penelitian ini Bertujuan untuk menjelaskan Gambaran Umum Strategi Guru dalam mengimplementasikan pendidikan Multikultural pada Sekolah dasar di Masa Pandemi Covid-19. Seiring dengan Terjadinya pandemi covid-19 serta dengan diterapkannya kebijakan social Distancing dan Physical Distancing dalam upaya untuk menurunkan Penyebaran Virus. Pada Penelitian Kali ini peneliti menggunakan metode Peneilitian Kualitatif dengan desain penelitian berupa Studi Kepustakaan(Library Research). Untuk Instrumen Penelitian yang digunakan yaitu berupa Dokumentasi dan juga Observasi. Berdasarkan Hasil Penelitian bahwa Implementasi nilai-nilai pendidikan Multikultural pada sekolah dasar di masa pandemi covid-19 bisa diterapkan dengan cara menanamkan ataupun menyisipkan Nilai-nilai Multuikultural itu sendiri ke dalam kompetensi inti pembelajaran baik berupa Dalam Jaringan (daring) dengan menggunakan Platfrom seperti Google Meet,Zoom,Whatsapp Group dan Google Classroom. Serta Luar Jaringan (Luring) dengan Menggunaan Buku Pegangan Peserta didik,Modul,LKS(Lembar Kerja Siswa) dan lainya. Adapun bentuk kegiatannya seperti a) Program yang berorientasi pada peserta didik.b) Program yang berorientasi pada Materi c) program yang berorientasi sosial.
\end{abstract}

Kata Kunci:Strategi Guru, Pendidikan Multikulturalisme,Pandemi Covid-19 


\section{PENDAHULUAN}

Indonesia menjadi salah satu bangsa yang mempunyai sumber daya alam yang kaya dan keragaman budaya. Tercatat sebagai negara yang memiliki 17.504 pulau, 1.340 suku bangsa, 746 bahasa dan enam macam agama yang berbeda. Keberagaman dan juga pupuk nilai toleransi yang tinggi dari bangsa Indonesia sendiri menjadikan negara Indonesia sebagai negara yang Baldatun toyyibatun warobbun ghofur. Namun, pada sisi yang lain, apa yang menjadi keuntungan ataupun keunggulan bagi negara Indonesia tersebut Rentan terhadap konflik yang melahirkan perpecahan antar bangsa Dalam beberapa dekade,negara Indonesia harus menghadapi beberapa konflik seperti konflik antar suku,agama,ras dan juga AntarGolongan(SARA). Padahal, keberagaman dan perbedaan yang sudah ada bukanlah alasan bagi individu maupun kelompok untuk dijadikan sarana saling membenci, melainkan menjadi sarana untuk saling menghormati dan saling menghargai antar satu dengan yang lain. Dalam firman Allah Subhanahu wa ta'ala Quran Surah Al-Hujurat ayat 13 dijelaskan

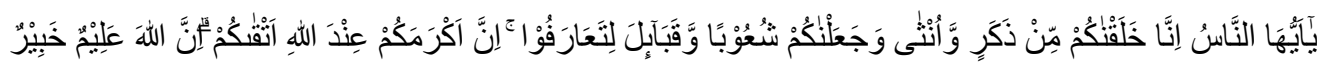

Artinya: Wahai manusia! Sungguh, Kami telah menciptakan kamu dari seorang laki-laki dan seorang perempuan, kemudian Kami jadikan kamu berbangsa-bangsa dan bersuku-suku agar kamu saling mengenal. Sesungguhnya yang paling mulia di antara kamu di sisi Allah ialah orang yang paling bertakwa. Sungguh, Allah Maha Mengetahui, Mahateliti.

Dari Arti QS. al-Hujarat ( $१$ १): $1 \%$, maka perbedaan yang terdapat pada manusia mulai dari jenis kelamin hingga kewarganegaraannya, merupakan suatu hal yang lumrah dan bukan menjadi alasan bagi setiap individu dan golongan untuk saling membenci apalagi menghancurkan antara satu dengan yang lain. Justru sebaliknya perbedaan yang ada hendaknya digunakan sebagai sarana untuk saling menghormati dan saling mengenal. Rafiuddin \& Ismail Suardi Wekke (2018: 103104) menyatakan perbedaan bukanlah merupakan hambatan dan cabaran untuk mewujudkan persatuan dan kesatuan nasional. bersatu bukan berarti harus menghilangkan perbedaan-perbedaan yang ada, di samping karena hal itu mustahil juga karena bertentangan dengan kodrat yang ada.

Berdasarkan penjelasan diatas maka bisa disimpulkan bahwa, salah satu upaya untuk mewujudkan keutuhan dan kesatuan banga dan negara adalah melalui pendidikan multikulturalisme. Pendidikan multikulturalisme adalah pendidikan yang berusaha untuk mengembangkan seluruh potensi yang ada pada diri manusia dalam rangka menghargai pluralitas dan heterogenitasnya sebagai konsekwensi dari keragaman budaya, etnis, suku dan aliran (agama). Pendidikan multikultural juga merupakan salah satu cara yang efektif untuk mewujudkan masyarakat multikultural di tengah semangat eksklusivitas yang berlebihan terhadap suku, agama, 
ras dan golongan nya. Aktivitas pendidikan dengan berbagai komponen yang ada di dalamnya adalah salah satu bentuk lembaga yang paling tepat untu menjembatani pengembangan pendidikan multikulturalisme. Baik melalui kurikulum pendidikan,pendekatan yang dilakukan oleh guru dan juga Strategi Pembelajaran.

Namun, Dewasa kini Pandemi Covid-19 masih terus berlanjut dengan menyebabkan lahirnya kebijakan physical dan social distancing untuk meminimalisir penyebaran wabah virus covid-19. Kebijakan ini pun berpengaruh pada pendidikan multikulturalisme yang terjadi di aktivitas kegiatan belajara mengajar pada institusi pendidikan. Selain itu, aktivitas belajar mengajar yang semula dilakukan secara tatap muka diubah menjadi pembelajaran Daring(Dalam Jaringan) pembelajaran seakan dibatasi oleh sekat-sekat imajiner pembelajaran virtual didepan layar yang dilakukan antara guru dan juga peserta didik. Ini menyebabkan aktivitas belajar mengajar lebih menyentuh aspek kognitif dan afektif peserta didik ketimbang aspek psikomotorik. Jika direlevansikan dengan konsep pendidikan multikulturalisme, maka pendidikan seharusnya memberikan Civic Value kepada peserta didik,sehingga mereka dapat memahami dan mengimplementasikan konsep pendidikan multicultural dalam kehidupan sehari-hari.

Di masa pandemic covid-19 yang diikuti dengan pemberlakuan pembelajaran daring dan luring.Guru dan Peserta didik kini juga dihadapkan dengan permasalahan lain yakni, keterbatasan kuota internet,susah sinyal yang terdapat didalam daerha terpencil,penilaian dalam aktivitas pembelajaran,pembelajaran praktik. Hal ini membuktikan bahwa tidak semua peserta didik akan mampu memahami pembelajaran pasa saat pembelajaran daring masih diterapkan.

Dari penjelasan latar belakang diatas maka penelitian bertujuan untuk mendeskripsikan tentang Strategi Guru dalam Mengimplementasikan Pendidikan multikultural pada sekolah dasar di masa pandemic covid-19.

\section{METODE}

Tulisan ini menggunakan desain penelitian Studi Kepustakaan(Library Research) dengan menggunakan pendekatan Kualitatif. Adapun penelitian pustaka yang dimaksud merupakan dalam tulisan ini yaitu suatu penelitian suatu penelitian yang menjadikan bahan pustaka sebagai sumber utama penelitian. Sedangkan pendekatan Kualitatif menurut eko sugiarto (2015:8) adalah metode yang temuan-temuannya tidak diperoleh melalui prosedur angka, statistik atau bentuk hitungan lainya dan bertujuan mengungkapkan gejala secara holistik-kontekstual melalui pengumpulan data dari latar alami dengan memanfaatkan diri peneliti sebagai instrumen kunci. Untuk instrumen pada penelitian ini peneliti menggunakan instrumen pengumpulan data berupa observasi dan dokumentasi.dengan analisis data penelitian dilakukan secara deskriptif. 


\section{HASIL DAN PEMBAHASAN}

\section{Strategi Guru,Pendidikan Multikultural dan Pandemi Covid-19}

Strategi merupakan suatu cara atau upaya yang dirancang untuk suatu proses yang akan dilaksanakan dengan maksud tujuan dan keinginan tertentu. Didalam aktivitas pembelajaran,Strategi sangat diperlukan untuk menunjang pembelajaran agar sesuai dengan tujuan dan keinginan.menurut Djamar dan Zain (Hamiyah dan Jauhar, 2014:8) Strategi pembelajaran merupakan konsep atau gambaran secara garis besar untuk menerapkan suatu tindakan pada saat proses pembelajaran untuk menggapai tujuan yang telah ditetapkan.

Dewasa kini,Guru masih menerapkan Strategi Pembelajaran yang terpusat pada pendidik yang seharusnya diarahkan ke peserta $\operatorname{didik}($ Student centered). Dengan perubahan Strategi Pembelajaran yang kita lakukan,mewajibkan Guru untuk kembali mempelajari Strataegi pembelajaran yang sesuai dengan era digital (Idrus, 2011:64). guru harus bisa mengubah Strategi Pembelajaran yang di ikututi zaman sekarang sehingga strategi guru dalam pembelajaran bisa efektif dalam hal mengajar peserta didik. Disinilah letak peran guru sebagai pendidik dan pengajar sangat diperlukan.

Menurut Husaini (Rusmini, 2012:4) peran guru dalam proses pembelajaran peserta didik 1. Guru sebagai perencana 2. Guru sebagai pelaksana 3. Guru sebagai penilai. guru harus mengerti akan tiga point penting peran guru dalam proses pembelajaran. Menurut Sardiman (dalam Widya, 2013:5) Peran guru sebagai komunikasi, sahabat yang bisa memberikan nasehat-nasehat dorongan, pembimbing dalam pengemangan sikap dan tingkah laku serta nilai-nilai orang yang menguasai bahan yang diajarkan. guru mampu menjadi sahabat ke peserta didik dan guru juga bisa memberikan motivasi ke peserta didik pentingnya proses pembelajaran.

Strategi Guru dalam mengimplementasikan strategi pembelajaran yang baik kepada siswa maka nilai kebersamaan juga akan lebih mudah dipahami, siswa akan dapat bersikap yang baik dengan lingkungan yang multikultural. Pendidikan multikulturalisme sangat penting di sekolah dasar, hal ini karena sekolah dasar merupakan jenjang pertama dalam dunia pendidikan anak.

Multikultural secara bahasa terdiri dari kata "multi" yang berarti banyak dan "kultur" yang diartikan sebagai budaya. Pengertian pendidikan multikultural dalam Sumber ajaran Islam memang tidak secara eksplisit disebutkan dengan istilah pendidikan multikultural. Namun dalam sejumlah ayat yang terdapat di dalam al- 
Qur'an, seperti QS. al-Baqarah (2): 213, QS. an-Nisa (4): 1, dan QS. al-Hujarat (49): 13.penjelasan dalam ayat tersebut telah memberi petunjuk manusia merupakan saudara senasab (anak keturunan bani Adam a.s.) dan dalam persaudaraan tersebut lalu diperkuat dengan adanya relasi persaudaraan seagama. sudah seharusnya bagi setiap Muslim mendamaikan dua kelompok Muslim lainnya yang sedang bertikai, melarang saling hina, merendahkan, mengejek, berprasangka buruk, mencari-mencari kesalahan dan menggunjing antar sesama.

Adapun definisi pendidikan multikultural menurut James Banks (dalam Subandi, 2017: 471) adalah suatu ide, gerakan, pembaharuan pendidikan, dan proses dari pendidikan itu sendiri dengan tujuan utama mengubah struktur lembaga pendidikan agar peserta didik yang berasal dari latar belakang yang berbeda memiliki kesempatan yang sama. Sedangkan menurut Musa (dalam Dani Nurcholis, 2019:131) pendidikan multikultural adalah proses penanaman cara hidup yang menghargai, ikhlas, dan toleran terhadap keragaman budaya yang hidup dalam masyarakat majemuk.

Dari kedua pendapat tersebut dapat disimpulkan bahwa pendidikan multikultural adalah suatu kegiatan pendidikan yang mengakui dan menghargai segala macam perbedaan yang ada pada manusia, baik berupa perbedaan agama, suku, ras, bahasa, dan gender. Selain menjadikan komponen pendidikan sebagai instrumen untuk menjembatani penyebaran dan perkembangan multikulturalisme.

Dilihat dari karakteristiknya, pendidikan multikultural menurut Choirul Mahfud (dalam Kuni Isna Ariesta Fauziah \& Mulkul Farisa Nalva, 2019: 216) memiliki ciri-ciri sebagai berikut: a) membentuk manusia yang berbudaya dan menciptakan masyarakat yang berbudaya/beradab. b) Mengajarkan nilai-nilai luhur kemanusiaan, nilai-nilai kebangsaan, dan nilai-nilai suku bangsa (budaya), c) metodenya demokratis, yang menghargai aspek perbedaan dan keragaman budaya bangsa. bangsa dan kelompok etnis (multikulturalis), d) evaluasi ditentukan pada penilaian perilaku siswa yang meliputi persepsi, penghargaan, dan tindakan mereka terhadap budaya lain.

Selanjutnya dalam kaitannya dengan tujuannya, menurut R. Ibnu Ambarudin (2016:37), pendidikan multikultural bertujuan untuk menanamkan rasa simpati, saling menghormati, menghargai, dan empati bagi pemeluk agama dan budaya yang berbeda. Selain itu menurut Zakiyuddin Baidhawy (2005:108). Sedangkan menurut Budianta (dalam Yenny Puspita, 2018: 27) pendidikan multikultural memiliki upaya mewadahi kegiatan pembelajaran yang memungkinkan peserta didik untuk mencapai potensi 
maksimalnya sebagai peserta didik dan sebagai individu yang aktif dan memiliki kepekaan sosial yang tinggi di tingkat lokal, nasional dan global. tingkat. tingkat. meratakan dan mewujudkan bangsa yang kuat, maju, adil, makmur, dan sejahtera tanpa perbedaan suku, ras, agama, dan budaya. Dengan semangat membangun kekuatan di segala bidang sehingga tercapai kesejahteraan bersama, memiliki harga diri yang tinggi dan disegani oleh bangsa lain.Dari penjelasan tersebut, tujuan pendidikan multikultural adalah kesadaran akan perbedaan dalam kehidupan bermasyarakat, berbangsa dan bernegara serta mampu menjadikan perbedaan tersebut sebagai wahana untuk mencapai tujuan bersama atau dalam semboyan bangsa Indonesia yang dikenal dengan Bhinneka Tunggal Ika. (berbeda, tapi satu). omong-omong). Upaya mengembangkan pendidikan multikultural bukan tanpa alasan. Keberagaman masyarakat Indonesia baik dari latar belakang ras, suku, agama dan bahasa, berpotensi menimbulkan konflik yang dapat mengancam persatuan dan kesatuan bangsa.

Namun sejak merebaknya Coronavirus Diseases 2019 (Covid-19) pada akhir tahun 2019, tepatnya setelah Komite Kesehatan Kota Wuhan, Wuhan, China pada tanggal 30 Desember 2019 mengeluarkan pernyataan "urgent notice on the treatment of pneumonia of unknown cause ". Maka dimulailah masa pandemi yang melanda hampir semua sektor kehidupan di dunia, mulai dari ekonomi, pariwisata bahkan pendidikan. Sejak diumumkannya kasus Covid-9 pertama kali di Indonesia pada 2 Maret 2020. Berbagai aktivitas masyarakat mulai dibatasi dengan dikeluarkannya kebijakan social distancing dan physical distancing dalam rangka memutus mata rantai penyebaran virus tersebut. virus corona.

Tidak hanya hubungan sosial. Covid-19 juga berimplikasi pada aktivitas belajar siswa di berbagai jenjang pendidikan. Hal itu ditandai dengan terbitnya surat Menteri Pendidikan dan Kebudayaan Republik Indonesia Nomor: 36962/MPK.A/HK/2020 tanggal 17 Maret 2020 tentang Belajar Online dan Bekerja dari Rumah Dalam Rangka Pencegahan Penyebaran Covid-19. Melalui surat tersebut, proses belajar dan bekerja yang biasanya dilakukan secara tatap muka, berubah menjadi bentuk pembelajaran online di rumah.

Sedangkan karyawan, guru, dan dosen dapat melakukan aktivitas kerja, mengajar atau memberikan kuliah dari rumah (Work From Home/BDR) melalui video conference, dokumen digital, dan sarana online lainnya. Pembelajaran online merupakan salah satu inovasi dalam bidang pendidikan untuk menjawab tantangan 
zaman. Pembelajaran online juga dapat diartikan sebagai metode pembelajaran yang menggunakan model interaktif berbasis internet dan learning management system (LMS), seperti zoom, google meet, google drive dan lain sebagainya. Kegiatan ini juga dapat dilakukan dalam bentuk webinar, kelas online dan lain-lain. (Hasibuan, dkk, dalam Anasia Malyana, 2020), dengan demikian pembelajaran online adalah pembelajaran yang menggunakan jaringan internet dalam proses kegiatannya.

Namun, sistem pembelajaran online kemudian digabungkan dengan pembelajaran offline. Pembelajaran offline merupakan kebalikan dari sistem pembelajaran online, dimana bentuk pembelajarannya sama sekali tidak terkoneksi dengan internet. Artinya pembelajaran dapat dilakukan dengan media seperti radio, televisi, buku pegangan siswa, modul, LKS dan lain-lain.

\section{Strategi Guru dalam Mengimplementasikan Pendidikan Multikulrulisme pada sekolah dasar di masa Pandemi Covid-19}

Isi pendidikan multikultural saat ini pada dasarnya tidak terlihat jelas eksplisit dalam silabus pembelajaran dan rencana pembelajaran (RPP).Namun, semangat dan konsep pendidikan multikultural pada dasarnya telah terintegrasi danterinternalisasi dalam kurikulum pendidikan nasional atau yang berlaku saat ini adalahKurikulum 2013 (K-13). Selain itu, substansi nilai pendidikan multikultural dalam ruang lingkup Ukuran yang lebih besar juga dapat dilihat pada mata pelajaran seperti Pendidikan Agama Islam (PAI)dan Pendidikan Kewarganegaraan (PKn). Dengan demikian, pelaksanaan pendidikan Multikulturalisme saat ini masih hanya menyisipkan berbagai kompetensi yang harus dimilikisiswa memiliki tentang multikulturalisme dalam mata pelajaran yang relevan karenaMultikulturalisme lebih mengacu pada sebuah gerakan dan belum menjadi sebuah ilmu terpisah.

Pada masa Pandemi Covid-19 pendidikan multikultural masih bisa dilakukan melalui pembelajaran online dan pembelajaran offline yaitu dengandalam tiga program kegiatan pembelajaran multikultural. Ketiga program tersebutantara lain yaitu: a) program berorientasi konten, b)program berorientasi siswa, dan c) program yang rogram berorientasi sosial (Sitti Mania, 2010: 86-87). penjelasan tentangketiga program tersebut. Pertama, program berorientasi materi dilakukan dengan memasukkan nilai-nilai pendidikan multikultural dalam kompetensi inti pembelajaran khususnya pada mata pelajaran Pendidikan Agama Islam(PAI) dan Pendidikan Kewarganegaraan (PKn). Nilai-nilai yang dimaksud adalah antara 
orang lain belajar untuk hidup dengan perbedaan, membangun rasa saling percaya,menjunjung tinggi sikap saling menghormati (mutual respect), terbuka dalam berpikir, saling ketergantungan,resolusi konflik, dan rekonsiliasi tanpa kekerasan (Sapsuha, M. Tahir, 2013:202). Selain daripada itu,pendidikan multikultural yang telah terintegrasi ke dalam setiap mata pelajaran dapat diamati dari apa kompetensi inti. Asfiati (2016: 144) menyatakan bahwa kompetensi inti dirancang dalam empat kelompok yang saling terkait terkait dengan sikap keagamaan ataukompetensi inti sikap spiritual (kompetensi inti 1/K-1), kompetensi inti sikap sosial (kompetensi 2/K-2), kompetensi inti pengetahuan (kompetensi 3/K3), dan kompetensi intipenerapan pengetahuan atau keterampilan (kompetensi 4/K4). Empat kelompokmenjadi acuan kompetensi dasar dan dikembangkan dalam setiap pembelajaran integratif.Sedangkan kompetensi terkait sikap keagamaan dan sosial dikembangkan tidak langsung (pengajaran tidak langsung).

Kedua, program yang berorientasi pada siswa.Program ini merupakan program yang bertujuan untuk meningkatkan prestasi akademik dan mahasiswa non akademik yaitu dengan menggali kemampuan dan potensi yang ada sendiri dengan berbagai pendekatan dan metode. Selain itu, kegiatan ini sebagaisalah satu model pembelajaran inovatif abad 21 dimana pembelajaran konvensional berorientasi atau berpusat pada guru (teacher centered) bergeser dengan pembelajaran yang Sedang belajar. Meski kegiatan ini tidak memberikan perubahan besar terhadap isi kurikulum, setidaknya bisa menjadi masukan(umpan balik) dalam penyusunan kurikulum berikutnya, terutama yang berkaitan dengan kontak sosial pendidikan, serta membantu siswa dengan keragaman untuk menciptakan perubahan dalam pendidikan arus utama.

Ketiga, program berorientasi sosial. Program yang berorientasi sosial, yaitu program-program yang berupaya mereformasi paradigma pendidikan, budaya pendidikan dan politik pendidikan untuk pendidikan yang berwawasan multikultural. Program ini bertujuan untuk meningkatkan kumpulan pengetahuan multikultural kepada siswa dengan melibatkan mereka secara langsung dalam kegiatan yang mengandung interaksi sosial dalam masyarakat. Melalui kegiatan ini diharapkan dapat memberikan dampak signifikan dalam meningkatkan toleransi budaya dan lahirnya sikap dan perilaku saling menghormati perbedaan yang ada. Selain itu, melalui kegiatan ini diharapkan dapat tercipta relasi kelompok antara 
suku dan ras dalam program belajar bersama tanpa membedakan perbedaan yang ada pada setiap individu. Dengan demikian, bentuk pendidikan multikultural ini lebih menekankan hubungan antara manusia dan berbagai bentuknya dan dapat ditingkatkan kurikulum dalam rangka meningkatkan kontribusi sosial yang positif antar kelompok etnis dan budaya, serta diharapkan dapat merekonstruksi hubungan antara masyarakat dan masyarakat sekolah.

Di masa pandemi, sulit untuk menerapkan pendidikan multikultural. Hal ini disebabkan ketergantungan pendidik dan peserta pada kuota internet, perbedaan gaya belajar setiap siswa, serta kondisi latar belakang geografi masing-masing daerah. Masalah-masalah ini membuat pembelajaran online menjadi tidak mungkin sepenuhnya berjalan dengan sukses untuk semua siswa dan perlu ditinjau kembali. Namun, beberapa cara pada dasarnya telah ditempuh untuk mengatasi hal tersebutpermasalahan tersebut, diantaranya melalui Peraturan Sekjen No 2020 Tentang Pedoman Teknis Bantuan Kuota Data Internet 2020, tegakkan sistemnya pembelajaran online dikombinasikan dengan sistem pembelajaran offline, atau dalam kolaborasi dengan pihak swasta dalam meningkatkan jangkauan dan jaringan internet di seluruh wilayah.

Namun Dari berbagai penjelasan yang telah diuraikan, implementasi dari Pendidikan multikultural bukanlah hal yang mudah atau hanya coba-coba.namun kegiatan ini membutuhkan kerja keras dan dukungan dari seluruh komponen pendidikan. Selain daripada itu,sebagai bangsa yang majemuk dengan berbagai permasalahan yang ada, setidaknya perlu referensi paten dan berasal dari beberapa negara sukses melaksanakan pendidikan multikultural.

\section{KESIMPULAN DAN SARAN}

Berdasarkan pembahasan yang telah dipaparkan, hal ini menunjukkan bahwa Pendidikan multikultural kini telah terintegrasi dengan materi pelajaran yang terdapat dalam kurikulum 2013. Tujuannya agar siswa dapat menghargai dan hargai semua perbedaan yang ada dan jadikan perbedaan tersebut sebagai status kewarganegaraan yang melekat padanya dan menjadi ciri kehidupan berbangsa dan patriotik. Meski begitu, hasil penelitian menunjukkan bahwa penyelenggaraan pendidikan multikulturalisme pada pandemi covid-19 dilakukan dengan tiga program kegiatan, yaitu ) program berorientasi konten, b) program yang program yang berorientasi pada siswa, dan c) berorientasi pada program program berorientasi sosial. Selain itu dilaksanakan pula pendidikan multikultural 
melalui pembelajaran online yaitu melalui aplikasi seperti grup whatsapp, zoom, dan googleruang kelas, maupun offline yaitu dengan menggunakan buku pegangan siswa, Lembar Kerja Siswa, dan lain-lain.

\section{DAFTAR PUSTAKA}

\section{Buku:}

Anggito, Albi \& Johan Setiawan. (2018). Metodologi Penelitian Kualitatif. Sukabumi: CV. Jejak.

Asfiati. (2016). Pendekatan Humanis dalam Pengembangan Kurikulum. Medan: Perdana Publishing

Baidhawy, Zakiyuddin. (2005). Pendidikan Agama Berwawasan Multikultural. Jakarta: Penerbit Erlangga.

Sugiarto, Eko. (2015). Menyusun Proposal Penelitian Kualitatif: Skripsi dan Tesis. Yogyakarta: Suaka Media.

Subagiyo, Aris. Wawargita Permata Wijayanti, Dwi Maulidatuz Zakiyah. (2017). Pengelolaan Wilayah Pesisir dan Pulau-Pulau Kecil. Malang: Universitas Brawijaya Press

\section{Artikel dalam Jurnal:}

Subandi. (2017). Menderadikalisasi Faham Radikal Melalui Pendidikan Multikultural dan Karakter Lokal di Lampung. Fikri: Jurnal Kajian Agama, Sosial dan Budaya. Vol. 2, No. (2), 457-484.

Sitti Mania. (2010). Implementasi Pendidikan Multikultural dalam Pembelajaran. Lentera Pendidikan. Vol. 13 No 1. 78-91.

Ambarudin, R. Ibnu. (2016). Pendidikan Multikultural untuk Membangun Bangsa yang Nasionalis Religius. Jurnal Civics: Media kajian Kewarganegaraan. Vol 13, No 1. 28-45.

Fauziah, Kuni Isna Ariesta Fauziah \& Mulkuk Farisa Nalva. (2019). Pendidikan Multikultural sebagai Strategi Deradikalisasi. Media Komunikasi Sosial Keagamaan. Vol. 19, No. 02. 208223.

Akhmad Hidayutullah al arifin.(2012). Implementasi Pendidikan Multikultural dalam Praksis pendidikan di Indonesia. Jurnal Pembangunan Indonesia. Vol 1, No 1. 72-82 